\title{
Isolasi Senyawa Terpenoid Dari Fraksi $n$-Heksana Daun Bilaran Tapah (Argyreia nervosa (Burm. F.) Asal Kalimantan Selatan
}

\author{
Sutomo $^{1,2^{*}}$, Putri Helena Junjung Buih ${ }^{2}$, Arnida ${ }^{2}$ \\ ${ }^{1}$ Pusat Studi Obat Berbasis Bahan Alam Universitas Lambung Mangkurat Banjarmasin \\ ${ }^{2}$ Program studi Farmasi FMIPA Universitas Lambung Mangkurat Banjarmasin
}

\begin{tabular}{l}
\hline \multicolumn{1}{c}{ Article info } \\
History \\
Submission: $08-08-2019$ \\
Review: $12-01-2020$ \\
Accepted: $13-07-2020$ \\
*Email: \\
Sutomo01@ulm.ac.id
\end{tabular}

DOI: $10.33096 /$ jffi.v7i1.527

Keywords:

Argyreia nervosa (Burm. F.); ethanol extract; isolation; identification; $n$-hexane

\begin{abstract}
One of the plants that is used empirically by people in South Kalimantan as a traditional medicine is bilaran tapah (Argyreia nervosa (Burm. F.). This plants that has purposed antiinflamation, antimicroba, antidiabetic, diuretic, and aphrodisiac. This research aims to isolate and explore the chemical compounds of n-hexana fraction of A. nervosa leaves. Extraction is conducted by using maceration method. Isolation is conducted by using Vacumn Liquid Chromatography and gravity chromatography column. Identification qualitative assay of compound used TLC test, UV-Vis and FTIR spectrophotometry. The extraction of 500 grams A. nervosa leaves rough powder with $96 \%$ ethanol extracts produces $16,92 \%$ of rendement. The fractionation of 30 grams ethanol extracts with n-hexane produces $23,60 \%$ of rendement. N-hexane fraction by using VLC with mobile phase n-hexane- ethyl acetate $(25: 1 ; 20: 1 ; 15: 1 ; 10: 1 ; 9: 1 ; 8: 2 ; 7: 3$; and $6: 4) v / v$ produces fractions $A, B, C, D, E, F, G$, and $H$. Fraction $C$ is chosen to be isolated by using column chromatography with mobile phase n-hexane: ethyl acetate $(20: 1) v / v$. TLC qualitative test with ammonia vapor, dragendorff, and Liebermann-Burchard reagent shows that C-4 isolates contains terpenoid compounds. Analysis of C-4 isolates by using UV-Vis spectrophotometry reach peak at $\lambda 245 \mathrm{~nm}$. Analysis FTIR spectra shows that the functional groups of $\mathrm{C}-4$ isolates are $-\mathrm{OH}(3309.85 \mathrm{~cm}-1),-\mathrm{CH}$ aliphatic $(2939.52 \mathrm{~cm}-1$ and $2870.08 \mathrm{~cm}-1), C=C(1635.64 \mathrm{~cm}-1)$ and $C$ $O(1033,85 \mathrm{~cm}-1)$.
\end{abstract}

\section{Pendahuluan}

Penanggulangan terhadap berbagai penyakit dengan memanfaatkan tumbuhan obat tradisional semakin banyak digunakan masyarakat seiring dengan slogan back to nature dan didukung oleh potensi tumbuhan obat yang cukup besar di Indonesia (Ayuni \& Sukarta, 2013). Senyawa metabolit sekunder merupakan senyawa kimia yang umumnya mempunyai kemampuan bioaktivitas dan berfungsi sebagai pelindung tumbuhan (Aksara et al., 2013). Kandungan senyawa tersebut penting diketahui untuk memperkirakan khasiat serta menentukan metode ekstraksi untuk mengisolasi zat aktif yang ada didalamnya (Atmoko \& Ma'ruf, 2009).

Kalimantan Selatan sebagai salah satu wilayah yang memiliki hutan yang kaya bahan alam dan berkhasiat sebagai obat. Salah satu tumbuhan yang digunakan sebagai obat tradisional adalah bilaran tapah (Argyreia nervosa (Burm. F.). Tumbuhan ini secara empiris digunakan oleh masyarakat Kalimantan selatan sebagai obat batuk dan demam (antipiretik). Hasil pendekatan biogenis memberikan informasi bahwa genus Argyreia memiliki aktivitas sebagai antiinflamasi, imunomodulator, antitumor, antidiabetes, hipoglikemia, spasmolitik, dan antimikroba (Srivastava et al., 1998; Joseph et al., 2011; Habbu et al., 2008). Hasil skrining fitokimia terhadap ekstrak etanol daun $A$. nervosa menunjukkan esktrak tersebut mengandung alkaloid, flavonoid, fenol, tanin, saponin, terpenoid, dan antrakuinon (Sutomo et al., 2016). Ermawati (2017) melaporkan bahwa ekstrak etanol daun $A$. nervosa berpotensi sebagai antimalaria.

Berdasarkan informasi di atas, maka perlu dilakukan eksplorasi senyawa dari fraksi $n$-heksana dari ekstrak etanol daun $A$. nervosa. Penelitian ini dimaksudkan untuk mengisolasi salah satu senyawa dari fraksi $n$-heksana menggunakan metode kromatografi cair vakum dan dilanjutkan dengan metode kromatografi kolom gravitasi. Data yang diperoleh dapat memberikan gambaran beberapa senyawa dalam fraksi $n$-heksana daun $A$. nervosa dan profil spektrum isolat menggunakan spektroskopi FTIR. Gambaran profil kromatogram dan spektroskopi isolat dapat dijadikan informasi ilmiah untuk penelitian yang lebih komprehensip 
dan pembanding dalam aktifitas terhadap senyawa yang serupa.

\section{Metode Penelitian}

\section{II.1 Pengambilan sampel dan Pembuatan} Serbuk Simplisia

Proses pengambilan sampel daun $A$. nervosa dilakukan di Daerah Rantau kabupaten Tapin, Kalimantan Selatan, yaitu di KHDTK Desa Kelumpang yang berada di bawah pengelolaan Balai Penelitian Kehutanan Banjarbaru. Daun A. nervosa yang telah disortasi basah dan dicuci selanjutnya dilakukan pengeringan dengan cara dikeringanginkan. Selanjutnya dilakukan sortasi kering dan penyerbukan menjadi serbuk kasar untuk memperluas permukaan bahan sehingga proses ekstraksi dapat berjalan maksimal (BPOM RI, 2013).

\section{II.2 Ekstraksi}

Proses ekstraksi dilakukan dengan metode maserasi yaitu serbuk kasar ditimbang sebanyak 1 $\mathrm{kg}$ dan dimasukkan ke dalam maserator. Ekstraksi menggunakan pelarut etanol $96 \%$ hingga $2 \mathrm{~cm}$ diatas permukaan sampel. Ekstraksi dilakukan selama 24 jam dan setiap 4 jam dilakukan pengadukan. Setelah disaring dilakukan remaserasi kembali sebanyak 2 kali dan semua ekstrak cair (filtrat) diuapkan menggunakan rotary evaporator suhu $60^{\circ} \mathrm{C}$ hingga didapatkan ekstrak kental, selanjutnya diuapkan kembali menggunakan waterbath hingga diperoleh ekstrak kental dengan bobot tetap.

\section{II.3 Fraksinasi}

Ekstrak yang diperoleh difraksinasi dengan metode ekstraksi cair-cair menggunakan $n$-heksana. Ekstrak ditimbang sebanyak 15 gram selanjutnya disuspensikan dengan akuades sebanyak 37,5 mL $(1: 2,5)$ dan dimasukkan ke dalam corong pisah. Pelarut $n$-heksana sebanyak $75 \mathrm{~mL}$ ditambahkan ke dalam corong pisah yang berisi suspensi ekstrak, digojog hingga terbentuk 2 lapisan. Senyawa yang larut dalam $n$-heksana berada di lapisan atas. Proses fraksinasi diulangi sebanyak 8 kali dan semua fraksi $n$-heksana diuapkan menggunakan rotary evaporator dengan suhu $50^{\circ} \mathrm{C}$ hingga didapatkan fraksi kental. Fraksi kental diuapkan kembali menggunakan waterbath hingga diperoleh bobot tetap sebagai fraksi $n$-heksana dan disimpan untuk dilakukan isolasi.

\section{II.4 Pengujian KLT}

Analisis kualitatif dilakukan terhadap tumbuhan uji menggunakan pereaksi semprot $\mathrm{H}_{2} \mathrm{SO}_{4} \quad 10 \%$ terhadap hasil KLT (kromatogram). Sampel dari ekstrak etanol dan fraksinya dilakukan uji KLT menggunakan fase gerak $n$-heksana-etil asetat $(9: 1) \mathrm{v} / \mathrm{v}$. Kromatogram diamati pada lampu UV $254 \mathrm{~nm}$ dan $366 \mathrm{~nm}$, selanjutnya disemprot dengan penampak bercak $\mathrm{H}_{2} \mathrm{SO}_{4} 10 \%$. Bercak yang muncul dicatat dan dihitung nilai $H R f$ nya (Dirjen POM, 1987).
II.5 Isolasi Senyawa Terpenoid Secara Ekploratif 1. Metode Kromatografi Cair Vakum (KCV)

Tiga gram fraksi $n$-heksana dielusi dengan gradien fase gerak campuran $n$-heksana-etil asetat $(25: 1 ; 20: 1 ; 15: 1 ; 10: 1 ; 9: 1 ; 8: 2 ; 7: 3 ;$ dan $6: 4) \mathrm{v} / \mathrm{v}$. Masing-masing fraksi menggunakan fase gerak sebanyak $200 \mathrm{~mL}$, sehingga secara berturut-turut didapatkan fraksi A, B, C, D, E, F, G, dan H. Fraksi hasil KCV diuapkan, selanjutnya dilakukan KLT. Isolasi dilanjutkan terhadap fraksi yang menunjukkan profil kromatogram yang baik dengan menggunakan kromatografi kolom (KK) gravitasi.

\section{Metode Kromatografi Kolom Gravitasi}

Kromatografi kolom dilakukan terhadap fraksi C dan D (hasil KCV) yang didasarkan dari profil kromatogram sebelumnya. Pada fraksi $\mathrm{C}$ dan D terdapat 2 bercak yang berpendar pada lampu UV $366 \mathrm{~nm}$ berwarna kemerahan pada HRf 55 dan putih pada $H R f 75$, sedangkan pada lampu UV $254 \mathrm{~nm}$ tidak menunjukkan bercak. Hasil KLT fraksi D terdapat 2 bercak yang nampak pada lampu UV 254 $\mathrm{nm}$ dan berpendar pada UV $366 \mathrm{~nm}$ dengan nilai $H R f$ sebesar 69 dan 80. Berdasarkan hasil elusi pengamatan terhadap kromatogram dan jumlah fraksi yang didapat, dipilih fraksi C untuk dilanjutkan ke tahap KK. Untuk pemeriksaan kemurnian isolat dilakukan dengan kromatografi lapis tipis $2 \mathrm{D}$, sedangkan untuk melihat gugus fungsi dari isolat dilakukan dengan spektroskopi FT-IR (Sastrohamidjojo, 2001; Pavia et al.,2001; Sutomo, 2014; Azhari, 2016).

\section{Pemeriksaan kemurnian dengan kromatografi lapis tipis (KLT) 2 dimensi}

Senyawa hasil isolasi dilakukan uji kemurniannya dengan KLT 2 dimensi menggunakan fase gerak dengan kepolaran yang berbeda. Fase gerak yang pertama digunakan adalah $n$-heksana : etil asetat $(9: 1) \mathrm{v} / \mathrm{v}$ dan fase gerak kedua digunakan yang lebih polar yaitu $n$-heksana : etil asetat $(8: 2)$ v/v. Jika bercak yang dihasilkan menunjukkan bercak tunggal maka dapat dikatakan bahwa isolat telah murni

\section{Identifikasi Isolat secara kualitatif}

Identifikasi dilakukan terhadap isolat menggunakan pereaksi spesifik untuk golongan flavonoid, alkaloid, dan terpenoid. Uji dilakukan melalui uji semprot terhadap kromatogram, yaitu flavonoid (diuapi dengan amonia), alkaloid (disemprot dengan dragendorff), dan terpenoid (disemprot dengan Liebermann-Burchard).

\section{Identifikasi senyawa aktif Spektrofotometri $U V$-Vis}

Sampel dilarutkan dengan $5 \mathrm{~mL}$ metanol p.a selanjutnya dimasukkan ke dalam kuvet, demikian juga dengan blanko. Larutan sampel dan blanko diukur pada panjang gelombang 200-800 nm (Silverstain et al., 1986; Sastrohamidjojo, 2001; Pavia et al., 2001; Sutomo, 2014; Azhari 2016). Data yang diperoleh dianalisis untuk mengetahui panjang gelombang dari isolat 


\section{Spektrofotometri Fourier-transform infrared spectroscopy (FTIR)}

Senyawa hasil isolasi (isolat) yang akan diukur digerus bersama $\mathrm{KBr}(0,2-0,5 \mathrm{mg}$ isolat +100 $\mathrm{mg} \mathrm{KBr}$ ). Campuran dikempa (dibuat pelet) dan pelet yang telah dibuat ditempatkan pada kisi $\mathrm{NaCl}$. Dilakukan pengukuran dengan alat FTIR didaerah bilangan gelombang tengah infra merah (4000-400 $\mathrm{cm}^{-1}$ ) pada resolusi $16 \mathrm{~cm}^{-1}$ (Silverstain et al., 1986; Pavia et al., 2001; Sastrohamidjojo, 2001; Sutomo, 2014; Azhari 2016). Data yang diperoleh dianalisis untuk mengetahui gugus fungsi dari isolat.

\section{III.Hasil Dan Pembahasan \\ III.1 Ekstraksi}

Hasil ekstraksi terhadap $1 \mathrm{~kg}$ serbuk kasar simplisia daun $A$. nervosa menggunakan pelarut etanol 96\% didaptkan ekstrak kental sebanyak

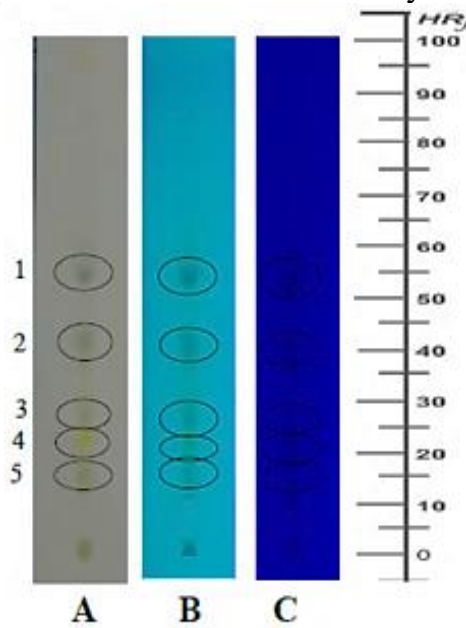

169,16 g (16,92\%)b/b. Karakteristik ekstrak secara organoleptik berwarna hijau tua, bau khas, dan rasa kas agak sepat.

\section{III.2 Fraksinasi ekstrak metanol daun $A$. nervosa dengan $\boldsymbol{n}$-heksana}

Ekstrak etanol sebanyak 30 gram difraksinasi dengan pelarut $n$-heksana. Fase $n$ heksana diuapkan di atas waterbath hingga diperoleh fraksi kental dengan bobot tetap. Fraksi kental $n$-heksana yang diperoleh adalah sebesar 7,08 g $(23,60 \%)$. Profil kromatogram dari fraksi $n$ heksana menunjukkan bercak dengan nilai $\operatorname{HRf} 16$, 23, 29, 43 dan 55. Hasil uji kromatografi lapis tipis fraksi $n$-heksana disajikan pada Gambar 1 .

Keterangan:

Sampel : fraksi $n$-heksana daun $A$. nervosa

Fase diam : silika gel $60 \mathrm{GF}_{254}$

Fase gerak : $n$-heksana : etil asetat $(9: 1) \mathrm{v} / \mathrm{v}$

Penampak bercak :

A : Visual

B : Lampu UV $254 \mathrm{~nm}$

C : Lampu UV $366 \mathrm{~nm}$

\section{Nilai $H R f$ fraksi $n$-heksana $A$. nervosa}

\begin{tabular}{ccccc}
\hline 1 & 2 & 3 & 4 & 5 \\
55 & 43 & 29 & 23 & 16 \\
\hline
\end{tabular}

Gambar 1. Kromatogram fraksi $n$-heksana daun A. nervosa

\section{III.3 Isolasi dengan Kromatografi Cair Vakum (KCV)}

Hasil KCV masing-masing gradien yang diperoleh di KLT dengan fase gerak n-heksana : etil asetat (8:2) v/v dan diidentifikasi dengan sinar UV $254 \mathrm{~nm}$ dan UV $366 \mathrm{~nm}$, serta pereaksi umum $\mathrm{H}_{2} \mathrm{SO}_{4} 10 \%$. Fraksi yang di KLT dikelompokkan sesuai dengan gradien fase gerak yang digunakan yaitu n-heksana-etil asetat (25:1); (20:1); (15:1); (10:1); (9:1); (8:2); (7:3); dan (6:4) sebagai fraksi A, B, C, D, E, F, G, dan H. Fraksi A, B, C, D, E, F, G, dan $\mathrm{H}$ masing-masing menunjukkan 1, 1, 1, 2, 1, 0, 2, 3, dan 1 bercak, dimana kromatogram disajikan pada Gambar 2. 


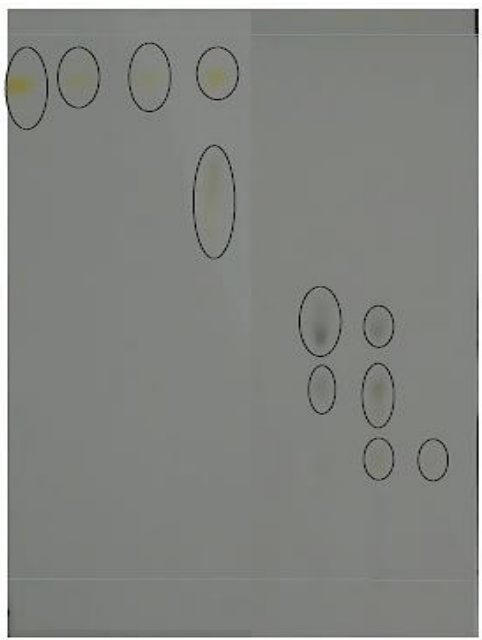

\section{Keterangan :}

A : fraksi A $n$-heksana:etil asetat $(25: 1) \mathrm{v} / \mathrm{v}$

$\mathrm{B}$ : fraksi B $n$-heksana:etil asetat $(20: 1 \mathrm{~B}) \mathrm{v} / \mathrm{v}$

$\mathrm{C}$ : fraksi C $n$-heksana:etil asetat $(15: 1 \mathrm{~A}) \mathrm{v} / \mathrm{v}$

$\mathrm{D}$ : fraksi D $n$-heksana:etil asetat $(10: 1 \mathrm{~B}) \mathrm{v} / \mathrm{v}$

$\mathrm{E}$ : fraksi E $n$-heksana:etil asetat $(9: 1 \mathrm{~B}) \mathrm{v} / \mathrm{v}$

$\mathrm{F}$ : fraksi F $n$-heksana:etil asetat (8:2 B ) v/v

$\mathrm{G}$ : fraksi G $n$-heksana:etil asetat $(7: 3) \mathrm{v} / \mathrm{v}$

$\mathrm{H}$ : fraksi H $n$-heksana:etil asetat (6:4) v/v

Fase diam silika gel $60 \mathrm{~F}_{254}$

Fase gerak $n$-heksana : etil asetat (8:2) v/v

Nilai HRf: secara visual

\begin{tabular}{cccccccc}
\hline A & B & C & D & E & F & G & H \\
\hline 92 & 92 & 92 & 93 & - & 53 & 53 & 28 \\
& & & 75 & & 46 & 46 & \\
& & & & & & 28 &
\end{tabular}

$\begin{array}{lllllllll}\text { A } & \text { B } & \text { C } & \text { D } & \text { E } & \text { F } & \text { G } & \text { H }\end{array}$

Gambar 2. Kromatogram dari fraksi $n$-heksana daun $A$. nervosa menggunakan KCV

\section{III.4 Isolasi dengan KK Gravitasi}

Fraksi yang dipilih untuk KK gravitasi adalah fraksi C karena memiliki jumlah yang relatif banyak. Setelah di KLT kembali dengan fase gerak $n$ heksana-etil asetat (9:1) didapatkan kromatogram dengan nilai $\operatorname{HRf} 75$ dan 55 seperti disajikan pada Gambar 3A. Isolasi dengan menggunakan KK gravitasi menggunakan fase gerak $n$-heksan-etil asetat $(20: 1) \mathrm{v} / \mathrm{v}$ didapatkan beberapa isolat yang terdiri dari isolat C-1, C-2, C-3, C-4, C5, C-6, dan $\mathrm{C}-7$. Isolat $\mathrm{C}-4$ merupakan isolat yang paling banyak berupa kristal berwarna putih berbentuk seperti jarum (Gambar 3C). Hasil KLT menggunakan fase gerak $n$-heksana-etil asetat (9:1) menunjukkan senyawa tunggal dengan dengan nilai HRf 55 (Gambar 3B). Identifikasi menggunakan pereaksi semprot Liebermann-Burchard menunjukkan bahwa isolat merupakan senyawa golongan terpenoid.

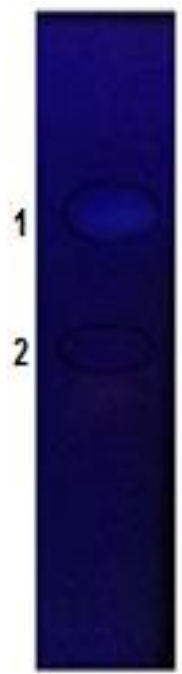

A

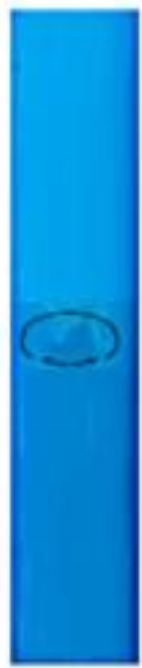

B

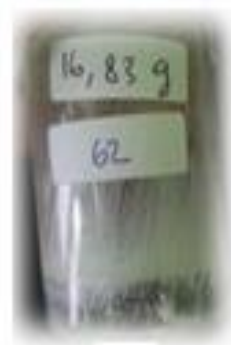

C

Gambar 3. Kromatogram fraksi C hasil KCV (A) dan kromatogram isolat dari hasil KK gravitasi (B) serta bentuk isolat $\mathrm{C} 4$

\section{III.5 Pemeriksaan Kemurnian dengan KLT 2 Dimensi}

Pemeriksaan kemurnian senyawa hasil isolasi dilakukan dengan uji KLT 2 dimensi. Fase gerak yang digunakan adalah (1) $n$-heksana : etil asetat $(9: 1) \mathrm{v} / \mathrm{v}$ dan (2) $n$-heksana-etil asetat $(8: 2) \mathrm{v} / \mathrm{v}$. Isolat menghasilkan bercak tunggal berwarna merah kecoklatan setelah disemprot dengan pereaksi
$\mathrm{H}_{2} \mathrm{SO}_{4} \quad 10 \%$ yang tampak secara visual dan pada lampu UV $254 \mathrm{~nm}$ seperti tersaji pada Gambar 4. 


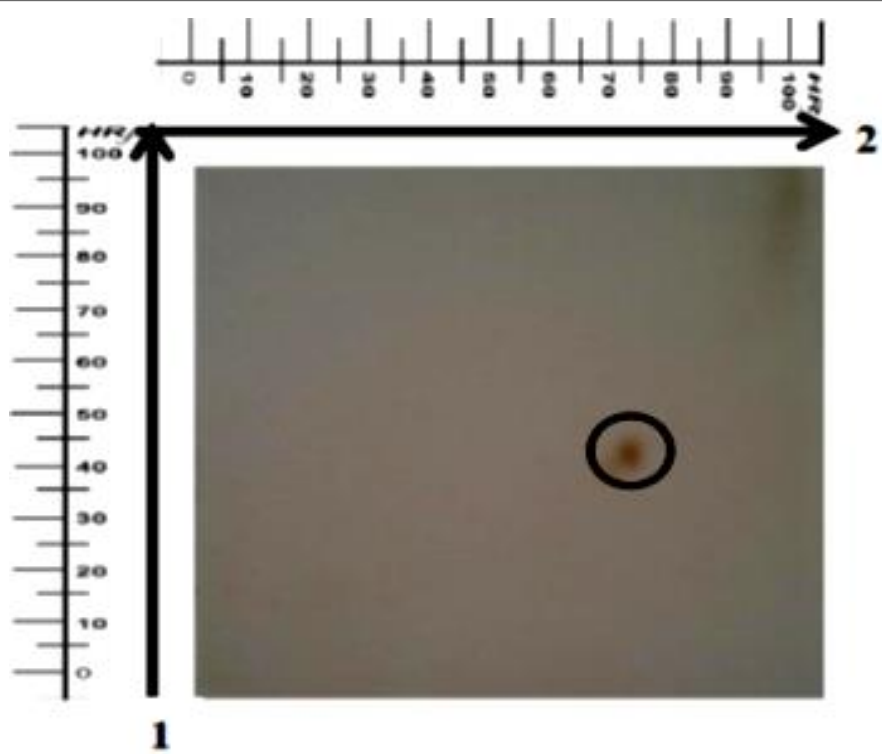

Gambar 4. Kromatogram dua dimensi dari isolat C4 hasil KK gravitasi

\section{III.6 Analisis data spektrum UV-Vis}

Hasil analisis isolat dengan spektrofotometri UV-Vis memberikan hasil berupa spektrum dengan serapan yang muncul pada panjang gelombang 245 $\mathrm{nm}$ dengan absorbansi sebesar 0,074. Munculnya serapan pada panjang gelombang $245 \mathrm{~nm}$ pada isolat C-4 merupakan akibat terjadinya transisi elektron kromofor berupa $\mathrm{C}=\mathrm{C}$ tak terkonjugasi. Transisi elektronik $\pi-\pi *$ terjadi pada daerah panjang gelombang $200-500 \mathrm{~nm}$ dan menunjukkan adanya ikatan rangkap tak terkonjugasi (-C-C $=\mathrm{C}-\mathrm{C}-\mathrm{C}-)$ (Fessenden \& Fessenden, 2006; Sastrohamidjojo, 2001; Harvey, 2000).

\section{III.7 Analisis data spektrum FTIR}

Data spektrum IR dari isolat menunjukkan pita-pita serapan pada bilangan gelombang tertentu yang kemudian dibandingkan dengan pustaka. Spektrum IR isolat C-4 menunjukkan pita serapan antara lain pada daerah bilangan gelombang $3309,85 \mathrm{~cm}^{-1}, 2909,32 \mathrm{~cm}^{-1}, 2870,08 \mathrm{~cm}^{-1}, 1635,64$ $\mathrm{cm}^{-1}, 1465,90 \mathrm{~cm}^{-1}$, dan $1381,03 \mathrm{~cm}^{-1}$. Pita serapan lebar antara 3600-3300 $\mathrm{cm}^{-1}$ yaitu $3309,85 \mathrm{~cm}^{-1}$ menunjukkan gugus hidroksi (-OH). Pita serapan tajam antara $3000-2850 \mathrm{~cm}^{-1}$ yaitu pada bilangan gelombang 2909,32 $\mathrm{cm}^{-1}$ dan 2870,08 $\mathrm{cm}^{-1}$ menunjukkan adanya gugus - $\mathrm{CH}$ alifatik yang diperkuat dengan adanya pita serapan tajam antara $1500-1400 \mathrm{~cm}^{-1}$ dan $1300-1000 \mathrm{~cm}^{-1}$ yaitu pada bilangan gelombang $1465,90 \mathrm{~cm}^{-1}$ dan $1381,03 \mathrm{~cm}^{-1}$ yang menandakan adanya gugus $-\mathrm{CH}_{2}$ dan $-\mathrm{CH}_{3}$ bending. Serapan pada rentang bilangan gelombang 1650-1500 cm $\mathrm{cm}^{-1}$ yaitu pada $1635,64 \mathrm{~cm}^{-1}$ menunjukkan adanya gugus $\mathrm{C}=\mathrm{C}$ alifatik. Pita serapan tajam antara $1300-1000 \mathrm{~cm}^{-1}$ yaitu pada bilangan gelombang $1033,85 \mathrm{~cm}^{-1}$ menunjukkan adanya serapan gugus C-O. Spektrum FTIR disajikan pada Gambar 5.

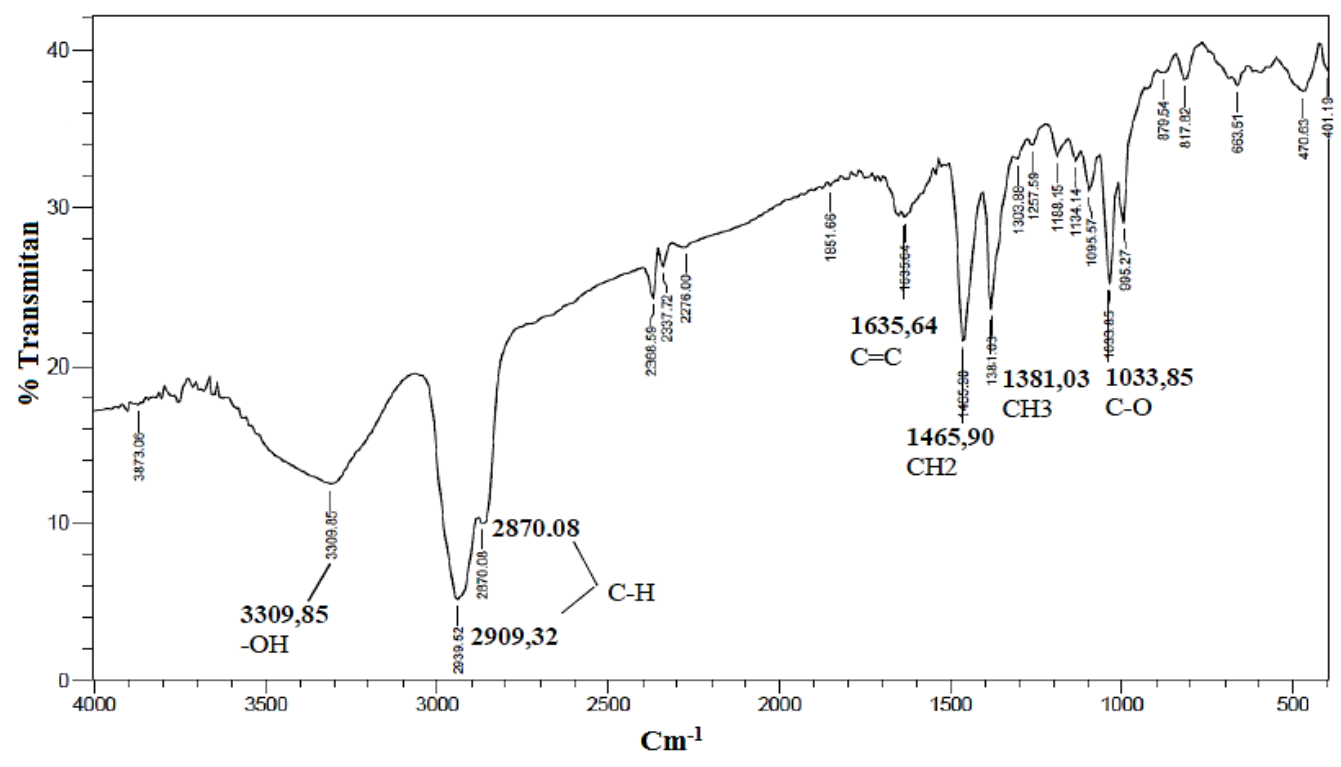

Gambar 5. Spektrum FTIR isolat C4 


\section{Kesimpulan}

Hasil identifikasi isolat menggunakan spektrofotometri UV-Vis menghasilkan puncak pada nilai $\lambda$ sebesar $245 \mathrm{~nm}$ yang diperkirakan adanya kromofor $\mathrm{C}=\mathrm{C}$ tak terkonjugasi. Hasil identifikasi isolat dengan spektrofotometri FTIR menunjukkan adanya gugus -OH $\left(3309,85 \mathrm{~cm}^{-1}\right)$, CH alifatik $\left(2939,52 \mathrm{~cm}^{-1}\right.$ dan $\left.2870,08 \mathrm{~cm}^{-1}\right)$ yang diperkuat dengan spektrum pada bilangan gelombang $1465,90 \mathrm{~cm}^{-1}$ dan $1381,03 \mathrm{~cm}^{-1}$ yang menunjukkan gugus fungsi $-\mathrm{CH}_{2}$ dan $-\mathrm{CH}_{3},-\mathrm{C}=\mathrm{C}$ $\left(1635,64 \mathrm{~cm}^{-1}\right)$, dan -C-O $\left(1033,85 \quad \mathrm{~cm}^{-1}\right)$. Identifikasi isolat dengan pereaksi LiebermannBurchard menunjukkan senyawa golongan terpenoid (triterpenoid).

\section{Ucapan Terima Kasih}

Ucapan terimakasih kepada Pusat Studi Obat Berbasis Bahan Alam ULM dan semua pihak yang membantu dalam penyelesaian penelitian ini.

\section{Daftar Pustaka}

Aksara, R., W.J.A. Musa, \& L. Alio. 2013. Identifikasi Senyawa Alkaloid dari Ekstrak Metanol Kulit Batang Mangga (Mangifera indica L.). Jurnal Entropi, 8(1): 514-519.

Atmoko, T. \& A. Ma'ruf. 2009. Uji Toksisitas dan Skrining Fitokimia Ekstrak Tumbuhan Sumber Pakan Oranguan terhadap Larva artemia salina L. (toxicity Testing and Phytochemical Screening of Orangutan Food Extracts to Larvae of Artemia salina L.)*). Jurnal Penelitian Hutan dan Konservasi Alam, 6(1): 37-45.

Ayuni, N.P.S. \& I.N. Sukarta. 2013. Isolasi dan Identifikasi Alkaloid pada Biji Mahoni (Swietenia mahagoni Jacq). Seminar Nasional FMIPA UNDIKSHA III. Hal: 387-393.

Azhari, A.H. 2016. Isolasi dan Identifikasi Senyawa Antioksidan dari Buah Kasturi (Mangifera casturi Kosterm.). Program Studi Farmasi FMIPA Universitas Lambung Mangkurat, Kalimantan Selatan.

Badan POM RI. 2013. Petunjuk Operasional Penerapan Cara Pembuatan Obat yang Baik Jilid I. Badan Pengawas Obat dan Makanan Republik Indonesia, Jakarta.

Dirjen POM. 1987. Farmakope Indonesia Edisi Ketiga. Departemen Kesehatan Republik Indonesia, Jakarta.

Ermawati. 2017. Aktivitas Penghambatan Polimerisasi Hem Ekstrak Etanol Daun Bilarang Tapah Asal Daerah Rantau Kalimantan Selatan. Skripsi. Program studi Farmasi, FMIPA, Universitas Lambung Mangkurat.

Fessenden R.J. \& J.R. Fessenden. 2006. Kimia Organik Edisi Ketiga Jilid II. Erlangga, Jakarta.
Habbu, P.V., R.A. Shastry, K.M. Mahadevan, H. Joshi, S.K. Das. 2008. Hepatoprotective and Antioxidant Effects of Argyreia speciosa in Rats, Afr J Trad Compl Altern Med, 5(2): 158.

Harvey, D. 2000. Modern Analytical Chemistry. Mc Graw-Hill ompanies, New York.

Joseph, A. S. Mathew, B.P. Skaria, \& E.C. Sheeja. 2011. Medicinal Uses and Biological Activities of Argyreian speciosa Sweet (Hawaiian Baby Woodrose)-An Overview. Indian Journal of Natural Products and Resources, 2(3): 286-291.

Pavia, D.L., G.M. Lampman, G.S. Kriz, \& J.R. Vyvyan. 2001. Introduction to Spectroscopy, Fourth Edition. Department of Chemistry, Western Washington University Bellingham, Washington.

Sastrohamidjojo, H. 2001. Dasar-dasar Spektroskopi. UGM Press, Yogyakarta.

Silverstain, R. M., G.C. Bassler, \& T.C. Morrill. 1986. Spectrometric Identification of Organic Compounds, Fourth Edition diterjemahkan oleh Hartono A.B. Penerbit Erlangga, Jakarta.

Srivastava, A., Y.N.Shukla, S.P. Jain \& S. Kumar. 1998. Chemistry and Pharmacology of The Elephat Creeper Argyreia speciosa- A review, Journal Medical Arom Plant Science, 20(3): 774-778.

Sutomo. 2014. Isolasi dan Identifikasi Senyawa Antioksidan dan Imunomodulator dari Buah Kasturi (Mangifera casturi Kosterm.) Suku Anacardiaceae. Disertasi Program Pascasarjana Program Studi Ilmu Farmasi Fakultas Farmasi, Universitas Gadjah Mada, Yogyakarta.

Sutomo, Arnida, M.I. Rizki, L. Triyasmono, A. Nugroho, E. Mintowati, \& Salamiah. 2016. Skrining Fitokimia dan Uji Kualitatif Aktivitas Antioksidan Tumbuhan Asal Daerah Rantau Kabupaten Tapin Kalimantan Selatan. Jurnal Pharmascience, 3(1): 66-74. 